\title{
Influences of Quality of Work Life (QWL), Work Discipline and Work Motivation on Employee Performance at the Department of Population and Civil Registration of Sumenep Regency
}

\author{
Dina Kurniawati ${ }^{1}$, Unsul Abrar ${ }^{2}$ \\ \{dinakurniawati@wiraraja.ac.id $\left.{ }^{1}\right\}$ \\ Department of Management, Universitas Wiraraja, Sumenep, 69451, Indonesia ${ }^{1,2}$
}

\begin{abstract}
Creating competitive advantage can improve quality of human resources; several advantages such as aspects of human resources are closely related to improve the quality of work life and several important aspects such as discipline of work and work motivation, as well as goals to set goals. This study focuses on examining the impacts of work quality, work discipline and motivation of work on employee performance at the Sumenep Regency Department of Population and Civil Registry. A method used in this study is a quantitative approach, due to limitations, for employees in the department with a population of 80 . A saturated sample of 80 participants was applied to a sample determination technique used for the office population. Multiple linear regression using SPSS software was used in a data analysis technique after data quality testing and assumption tests. The results of this study concluded that quality of working life has a significant impact on the performance of workers, variable discipline in the workforce also significant impacts on the performance of employees, and motivation for the work can also make a positive contribution to the population of the Department of Population and Civil Registration of Sumenep Regency.
\end{abstract}

Keywords: Quality of work life, work discipline, work motivation, employee performance

\section{Introduction}

The main problems with the management of human resources are how to build a production culture within a company to improve organizational performance [1]. According to Simanjuntak, in the performance aspect, levels of achievement for implementation of certain tasks Improving working life quality is not easy because there are so many challenges in its process; moreover, if not supported by various parties, this effort can fail [2]. Motivation and support from top management are needed in determining employee performance. Effective disciplinary action will encourage individuals to improve performance that benefits for the individuals and also the organization.

The main problem in this research is to complement a previous research, specifically the analysis of community satisfaction at this department. The previous study was still limited to general services to the community, so it is necessary for this study to conduct more in-depth research. This study focuses on how human resources in the office work optimally as it needs 
for development in terms of quality of work life, work discipline, and motivation of these employees in serving communities in Sumenep Regency. Another main problem is related to the implementation of Performance at the Sumenep Regency Department of Population and Civil Registration; there are still limited relationships to the implementation of work as there is no a positive reciprocal relationship between leaders and employees. Therefore, this needs for improvement in a better direction such as discipline, motivation or quality. For a better work life, motivation is a stage in achieving goals of effective performance by providing appropriate rewards or compensation, while in the quality of work life it is necessary to have equal participation from all human resources. Work motivation that affects performance and effective discipline will encourage individuals to improve performance that benefits for both the individual or the organization. Based on the discussions above, the variables of quality of work life, work discipline and work motivation are main research points in organizations engaged in the service sector. This study will focus on the performance of employees in the Sumenep Regency Department of Civil Registration. This study looks for how relationships between quality work of life, work discipline, and work motivation at the department.

The purpose of this study is how to provide solutions to problems that exist in an organization, especially in organizations that are engaged in public service with the research process of several predetermined variables. This research method utilizes quantitative methods with multiple linear regression methods. Partial tests and simultaneous tests are used to determine the final study outcome.

\section{Methods}

Indicators used in this study referred to Walton's quality work of life that consists of growth and development, participation, innovative reward systems, and work environment [3]. Meanwhile, according to Sudarmato, work discipline variables consist of punctuality, good use of office equipment, high responsibility, and obedience to office rules [4]. Next, work motivation consists of several indicators elaborated by Abraham Maslow into five hierarchies of needs: physiological needs, security needs, social needs, self-esteem and updating [5]. Meanwhile, according to Robbins, performance consists of several dimensions such as quality, quantity, timeliness, effectiveness, independence, and work commitment [6]. From these indicators, the authors developed some statements included in questionnaires to be answered by all research respondents. Next, A scale of data measurement in this study was an ordinal scale using five scales on each variable.

The population in this study were employees who work at this department. Its sampling technique used saturated samples, where all members of the population were sampled. The samples in this study were 80 employees. An analysis technique used in the first stage was conducted by testing the quality of the data by testing their validity and reliability, and then the data was also tested by five assumption tests. A multiple linear regression analysis is performed in order to examine the relationships between variables and to model them. Multiple regression is often used to solve regression analysis problems resulted from the relationships of two or more independent variables, and a related framework of this research can be seen in Figure 1 below. 


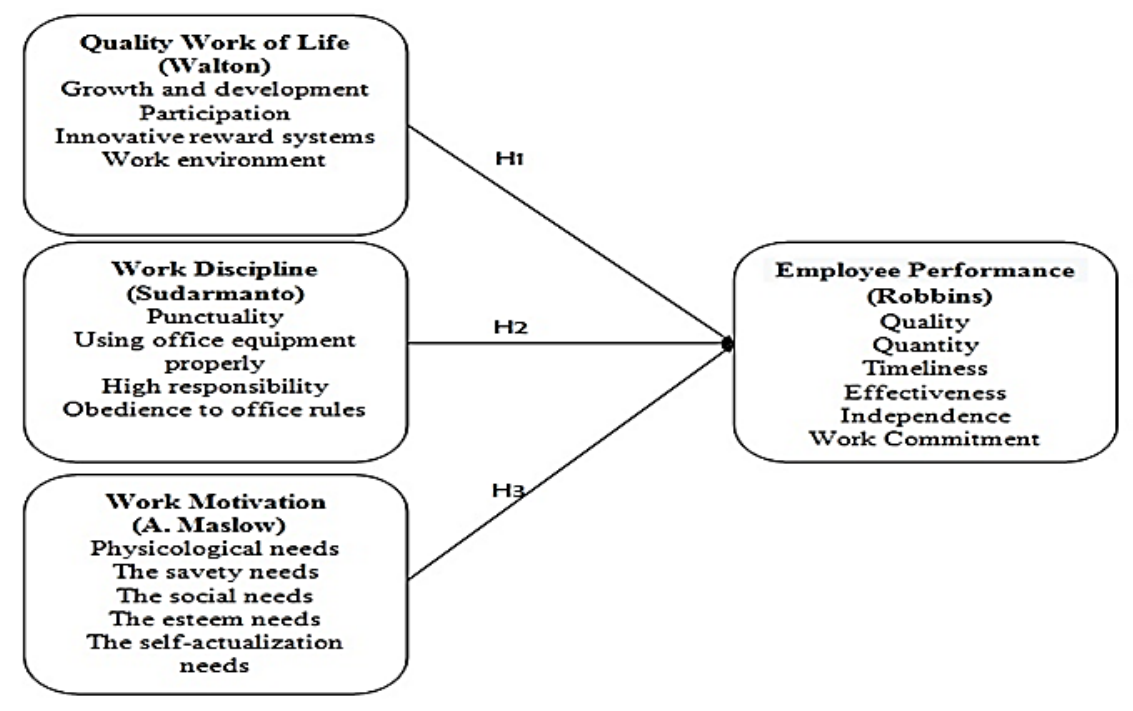

Fig. 1. Framework

\section{Results and Discussion}

\subsection{Results of the analysis}

\subsubsection{Multiple linear regression analysis}

The following Table 1 shows how to determine regression equations of this study according to the multiple linear regression analysis test.

Table 1. Multiple linear regression analysis

\begin{tabular}{llll}
\hline Model & \multicolumn{2}{l}{ Unstandardized Coefficient } & Significance \\
& B & Std. Error & \\
\hline Constant & 4,887 & 2,962 &, 103 \\
X1 &, 563 &, 112 &, 000 \\
X2 &, 443 &, 096 &, 000 \\
X3 &, 210 &, 091 &, 023 \\
\hline
\end{tabular}

From table 1 above, it is found that the regression equation is $\mathrm{Y}=4,887+0,563+0,443+$ 0,210 ; with a conclusion that if the three variables of this study show a constant value, the performance variable has a value of 4,887 , with values of each regression coefficient variable, namely $0,563,0,443$ and 0,210 .

\subsubsection{T test (Test individually)}

Individual test or t test is presented in the table below with reference to the $t$ test value and the significance value for each of the following variables. 
Table 2. $t$ Test

\begin{tabular}{lll}
\hline Variable & Test t & Significance \\
\hline X1 & 5,016 &, 000 \\
X2 & 4,627 &, 000 \\
X3 & 2,312 &, 023 \\
\hline
\end{tabular}

Based on Table 2, it shows that the value of the quality of work, work discipline and work motivation is less than 0.05. All these variables have a significant impact on the performance of employees.

\subsubsection{The calculated F test (simultaneous test)}

The joint test or the $\mathrm{F}$ test is presented in the table below with reference to the $\mathrm{F}$ test value and the significance value of each of these variables.

Table 3. Simultaneous Test (F)

\begin{tabular}{lll}
\hline Variable & F Test & Significance \\
X1 & & \\
X2 & 23,273 &, 000 \\
X3 & & \\
\hline
\end{tabular}

Table 3 shows that the significance value is still below 0.05 Therefore it can be concluded that all variables have an important performance effect.

\subsubsection{Test of the coefficient of determination}

Table 4 shows how all the independent variables contribute to the dependent variable.

Table 4. Test of the coefficient of determination

\begin{tabular}{llc}
\hline $\mathrm{R}$ & $\mathrm{R}$ Square & Adjusted R Square \\
\hline 692 &, 479 &, 458 \\
\hline
\end{tabular}

Based on Table 4, the influences of the all variables have an effect on performance by $47,9 \%$, while the remaining, $52,1 \%$, is influenced by other variables that cannot be researched.

\subsection{Discussion}

\subsubsection{Effect of quality of work life on employee performance}

The quality of work variable has a significant impact on the performance of employees. The quality of the working life of the employee of the service is lower and will reduce their performance. The performance of the employees is determined by how they improve the quality of life at this department.

The results above are also in accordance with Wayne' study stating that the quality of working life is perceptions of employees that they want to feel safe, feel satisfied, and got opportunity to be able to grow and develop like humans [3]. The results of this study also agree 
to several previous research results, including Anugrahini's study concluding that the quality of work life has a positive effect on employees of the Sampang Regency Industry and Trade Service [7]. Astrianditya's other study indicated that quality of work life has a positive impact on employees' performance, with several supporting factors, such as self-recognition, good working conditions and mutual tolerance, leaders' attitudes, which can promote, and manage, and suitable work placements so that quality of work affects employee performance [8].

Based on the discussions above, it can be a reference that the quality of work life at this department has a very good impact on continuity of working life and for improving performance in the office; This result is also in accordance with several things that occur in the field that several indicators such as development, participation, reward systems and work environment synergize with each other in the office with some evidence such as active participation of employees in carrying out activities every day with consistency of attendance and a conducive working environment, such as mutual intimacy between employees so that with this atmosphere a good work environment can arise and this variable can improve employee performance.

\subsubsection{The effect of work discipline on employee performance}

This variable shows that they influence employee performance positively. It can therefore be concluded that the work discipline which has become a culture or routine for these employees could improve individual workforce performance. Therefore, if discipline in these employees is declining, it will have an important impact on the performance of the department's employees.

This study found that levels of participation indicated by attendance at this department are in accordance with existing procedures at the office. The attendance factor is a basic reference for increasing employee discipline as attendance and adherence to work standards will have a very high impact on the performance of employees. This study is also supported by a previous theory since Ardana said that the discipline of work is a respect, observance, obedience, and compliance, both in writing and in writing, with the applicable regulations [9].

Meanwhile, another previous study by Rhyme and Bambang also strengthens the results of this study. The Rhyme and Bambang' study concluded that work discipline of employees is in a good category. Employees are aware that it is important to comply with existing company rules so that the company's work discipline has an important effect on its employee performance [10]. Suparno's study also endorses the positive and significant effect of work discipline on the performance of education employees in Sragen Regency. [11]

\subsubsection{The effect of work motivation on performance}

The results of several data tests to determine the effect of motivation on the performance of employees in the Department of Population and Civil Register of Sumenep Regency found that motivation for employee work influence the performance of employees. It can be concluded that the work motivation possessed by employees at the service can increase the performance of individual employees in the service; consequently, if there is work motivation on these employees, it will affect the decline of the employee performance at the department. 


\section{Conclusion}

The quality of work life can make a significant contribution to the performance of employees. Many important indicators such as the development, participation and supporting work atmosphere that has become a departmental routine and culture can be seen. These results show that the higher the quality of the work life of employees, the higher the performance of employees in the department. Employee discipline also helps employees in the department as these variables have a positive effect on employee achievement with certain criteria such as attendance, adherence to work standards, awareness, and the motivation for employees to work contributes positively to departmental performance because it shows that motivation for work has an important impact on employee performance.

\section{References}

[1] M. Hasibuan, "Human resource management", Jakarta: PT. Bumi Aksara, 2012.

[2] V. Rivai, "Human resource management for companies third edition", Jakarta: Rajawali pers, 2015.

[3] K. Tigor Sitorus, "Quality of work life, self efficacy, and employee performance: the mediating effect of work motivation (study at PT Bank BRI BSD branch)", Journal of management, vol. 13, no. 2, pp. 198-224, 2016.

[4] H. Hartanti, "The influence of competence, work discipline, education and training on employee performance at the Bantul trade office", Yogyakarta: Magister Management STIE Widya Wiwaha, 2018.

[5] E. Sari, " Abraham Maslow's hierarchical approach to employee performance of madubaru limited company (PG Madukismo) ", Journal of business behavior and strategy, vol. 6, no. 1, pp. 58-77, 2018.

[6] Rosman, "Analysis of employee performance in government administration in Sambaliung subdistrict, Berau district", E-journal of government science, vol. 2, no. 2, pp. 2753-2766, 2014.

[7] S. Anugrahini Irawati, "The influence of the quality of work life on the performance of employees of the Sampang District Industry and Trade Service", Neo-bis Journal, vol. 9, no. 2, pp. 41-52, 2015.

[8] A. Januar Ristanti and. F. Nurdiana Dihan, "The Effect of Quality of Work Life and Job Satisfaction on Employee Performance of Pt Pertamina Persero Ru Iv Cilacap", Assets: Journal of Accounting and Education, vol. 5, no. 1, pp. 53-64, 2016.

[9] I. Komang Ardana, N. Wayan Mujiati and I. Wayan Mudiartha Utama, "Human Resource Management", Yogyakarta: Graha Ilmu, 2012.

[10] R. Dwining Tyas \& B. Swasto Sunuharyo, "The influence of work discipline and work environment on employee performance (studies on employees of PT. Pertamina (Persero) Refinery Unit IV Cilacap)", " Journal of Business Administration (JAB), vol. 62, no. 1, pp. 172-180, 2018.

[11] Suparno and Sudarwati, "The influence of motivation, work discipline and competence on the performance of the education office employees," Journal of paradigm, vol. 12, no. 01, pp. 12-25, 2014. 